Article

\title{
Politicized Transnationalism: The Visegrád Countries in the Refugee Crisis
}

\author{
Michael Koß ${ }^{1, *}$ and Astrid Séville ${ }^{2}$ \\ ${ }^{1}$ Center for the Study of Democracy, Leuphana University Lüneburg, 21335 Lüneburg, Germany; \\ E-Mail:mkoss@leuphana.de \\ ${ }^{2}$ Geschwister-Scholl-Institute of Political Science, LMU Munich, 80538 Munich, Germany; \\ E-Mail: astrid.seville@gsi.uni-muenchen.de \\ * Corresponding author
}

Submitted: 16 August 2019 | Accepted: 10 December 2019 | Published: 13 February 2020

\begin{abstract}
Existing research on the evolution of European integration has pitted economic against identity issues. In the economic sphere, governments are arguably able to pursue their preferences more independently. If, however, identity issues become politicized this is supposed to suggest that governments lose their dominant position in integration and gradually become agents of Eurosceptic parties and/or electorates. This article looks at a phenomenon neither the intergovernmentalist nor the postfunctionalist perspective can fully explain: the emergence of the Visegrád Group (V4) as a collective actor in European politics in early 2016. This emergence occurred in the wake of the refugee crisis during which the identity issue of migration was politicized. However, there was no coherent partisan composition uniting V4 governments. Based on a sequence elaboration of all press statements of meetings of the V4 Prime Ministers since their EU-accession in 2004, we show that what at first sight appears to be informed by anti-immigrant and Eurosceptic sentiments may in fact display a more ambivalent position towards regional integration. The post-refugee crisis V4 appears as a case of politicized transnationalism - that is, cooperation to achieve transnational interests under the condition of politicization. This transnational interest not only comprised opposition to a relocation of migrants, but also the maintenance of a core transnational freedom within the EU, namely free movement under the Schengen acquis. We conclude that, under the condition of increasing politicization, identity issues help to forge government alliances of governments pursuing economic preferences.
\end{abstract}

\section{Keywords}

European integration; politicization; refugee crisis; transnational cleavage; transnationalism; Visegrád Group

\section{Issue}

This article is part of the issue "Political Behavior in the EU Multi-Level System" edited by Daniela Braun (LMU Munich, Germany), Martin Gross (LMU Munich, Germany) and Berthold Rittberger (LMU Munich, Germany).

(C) 2020 by the authors; licensee Cogitatio (Lisbon, Portugal). This article is licensed under a Creative Commons Attribution 4.0 International License (CC BY).

\section{Introduction}

Migration in general and the so-called refugee crisis in particular can be regarded as the most important incident of the politicization of Europe. In combination with traditional Euroscepticism (Szczerbiak \& Taggart, 2008), opposition to immigration allowed right-wing populist parties to poll new record shares of the vote throughout Europe (e.g., Börzel \& Risse, 2018). At the same time, analyses of post-2015 European politics hint at new regional alliances emerging in the EU, largely pitting countries affected and unaffected by immigration from out- side Europe against each other (e.g., Biermann, Guérin, Jagdhuber, Rittberger, \& Weiß, 2019; Zaun, 2018).

The perhaps best-known of these alliances is the Visegrád Group (V4), consisting of Poland, Hungary, the Czech Republic, and Slovakia. Existing since 1991 as a forum aiming to collectively achieve EU membership, cooperation among V4 states hit rock bottom at the moment this goal was reached in 2014 (Nič, 2016, p. 283). However, in the wake of the refugee crisis, the V4 began to formulate common positions and in February 2016, they successfully vetoed the implementation of a relocation scheme for migrants within the EU. All of a sudden, 
the V4 appeared as the "castle where a central European bloc was born" (Thorpe, 2016). This is even more remarkable since the newly revived cooperation outlived all changes to the partisan composition of V4 governments since then. The success of radical right-wing parties in East Central East European countries varies widely (Bustikova \& Guasti, 2018). Both Poland and Hungary are currently governed by Eurosceptic nationalist and populist parties. In contrast, similar parties are in opposition in the Czech Republic and in Slovakia. Irrespective of the partisan composition of their governments, the V4 continue to refuse any compulsive relocation of migrants within the EU and, in March 2019, succeeded to take this topic effectively off the agenda of the EU Council meeting (see Beisel, 2019).

The question we ask in this article is whether the politicization of migration politics stemming from the refugee crisis has led to closer cooperation among V4 alliance. The puzzle underlying our case study of one of the allegedly most virulent transnational challengers of supranational integration is that neither integration theory occupied with incidents of deadlock is able to explain why the V4 were successful. At first sight, and in line with postfunctionalist assumptions (Hooghe \& Marks, 2009, 2018), the newly revived V4 cooperation seems to be a typical consequence of the politicization of identity issues such as migration in the wake of the refugee crisis. But why then did it continue irrespective of the partisan composition of V4 governments, thus defying the electoral connection between government action and voter preferences postfunctionalism emphasizes? If V4 cooperation was less attached to electoral considerations and confined to the governmental arena, what was the economic interest liberal intergovernmentalism could base on this position-taking towards European integration (see Moravcsik, 1998)?

In order to explain why the V4 could become the 'castle' of the Central European bloc, we aim to elaborate the frequency, length, thematic focus on topics (especially those related of either identity or economics), and sequence of self-commitments to collective action on the top level of the V4 format, that is, the regular meetings of the V4 Prime Ministers. The press statements following these meetings are agreed on by all V4 governments. Despite being non-binding, they can be regarded as credible commitments on behalf of the V4. Our analysis suggests that the heads of the $\mathrm{V} 4$ governments did indeed increasingly commit themselves to pursue common policy goals after 2015 . These goals were ambivalent towards regional integration. The V4 simultaneously aimed to avoid a relocation of migrants, but also to preserve one of the core transnational freedoms within the EU, namely free movement under the Schengen acquis.

Our analysis proceeds as follows: In the following section, we shed light on the peculiar relation between migration within and into the EU. Immigration from outside the EU is understood as a danger to a core achievement of European integration, the Schengen acquis that allows for free movement (that is, migration) within the EU. In the third section, we introduce the Visegrád format and assess incentives and disincentives for the V4 to cooperate. The fourth section illustrates that both intergovernmentalism and postfunctionalism have difficulties to explain increased V4 cooperation. For intergovernmentalism, the public still plays a marginal role in European politics. Its major actors are governments responding to (organized) economic interests (liberal intergovernmentalism) or, in the absence of these, security concerns (realist intergovernmentalism). From a postfunctionalist perspective, united action of governments with different partisan compositions is at odds with the existence of a transnational cleavage (Hooghe \& Marks, 2018). The fifth section provides our empirical analysis of press statements following meetings of the V4 Prime Ministers since the EU accession of Poland, Hungary, the Czech Republic, and Slovakia in 2004. From this analysis we conclude that, under the condition of increasing politicization, postfunctionalist identity issues can forge liberal intergovernmentalist alliances of governments pursuing economic preferences. We term V4 cooperation a case of politicized transnationalism-that is, cooperation to achieve transnational aims such as the maintenance of freedom of movement under the condition of politicization.

\section{Migration within and into the EU}

The need for a European regulation of an identity issue such as migration originally arose from economic integration. The free movement of goods reached in the Single European Act rendered it necessary to also regulate the movement of European citizens - that is, migration. Already the EU's 1951 founding Paris Treaty that established the European Coal and Steel Community included free movement provisions for workers in these industries. The right to free movement was initially granted to workers only but has since been extended across categories to become a more general right. The Schengen Agreement of 14 June 1985 brought France, Germany, and the Benelux countries together in a far-reaching attempt to abolish border controls. The Dublin Convention of June 1990 provided that an asylum seeker would be required to make an asylum claim in the EU state where she or he arrived. Since the 1999 Treaty of Amsterdam, the Schengen Treaty is part of EU law. So is the Dublin Convention since 2003. By 2014, 26 European countries were Schengen members and all new member states are required to join as a condition of membership.

The result of the increased regulation of migration at the EU level is the partial institutionalization of common migration and asylum policies. The Dublin system is the main pillar of the Common European Asylum System (CEAS). The CEAS encompasses several different regulations that were adopted between 1999 and 2005. There is still no general EU admission policy, but there are EU laws covering asylum, the return and expulsion of 
third country nationals, family migration, the rights of migrants who are long-term residents, highly qualified migrant workers, seasonal migrant workers, and a single permit directive linking work and residence (Geddes \& Scholten, 2016, p. 146). The 2009 Lisbon Treaty finalized the creation of a common migration and asylum policy with Qualified Majority Voting, co-decision on legislation between the Council and the European Parliament, and full jurisdiction for the Court of Justice of the EU (Geddes \& Scholten, 2016, p. 152). In sum, the member states remain central actors, but they now share power with each other and with other actors, most notably EU institutions.

The Schengen principle of open internal borders with compensating security measures at EU borders can be regarded as "one of the most prestigious EU projects" (Biermann et al., 2019, p. 253). Once people are in the Schengen area-and have cleared immigration control in a Schengen country-they can essentially move freely in all EU member states except Britain and Ireland, but including the non-EU member states Norway and Iceland. When people are asked what the EU means to them, it is common for the first answer to be 'free movement.' This is also reflected by the self-perception of EU actors (see Geddes \& Scholten, 2016, p. 151).

Rather than migration within the EU, immigration into the EU has recently become the most pressing issue warranting regulation in the wake of the so-called refugee crisis. There were some 435,000 applicants for asylum in the EU in 2013. This number rose to over 960,000 in 2015 (Geddes \& Scholten, 2016, p. 156). Increasing immigration led to a de facto suspension of the Dublin system that was no longer enforced. In sum, the Schengen acquis was effectively suspended. In the summer of 2015, Hungary constructed a fence at its borders with Serbia and Croatia to stop onward movement of migrants who had entered the EU in Greece. When Germany reintroduced temporary controls on its border with Austria in September 2015, this caused a domino effect unleashing a wave of unilateral border closings and caps for asylum seekers throughout Europe. In November 2015 the Dutch, Austrian, and German governments even launched the idea of narrowing 'Schengen land' to only those countries really willing and able to control their external border (Geddes \& Scholten, 2016, p. 154).

The European Commission proposed three policy packages over the course of 2015 in order to maintain the Dublin system and preserve the Schengen acquis. As Biermann et al. (2019, p. 254) point out, all of these packages await decision-making or implementation or were substantially watered down. By 30 March 2017, a mere 15,000 refugees were relocated under the proposed voluntary ad hoc relocation scheme for 160,000 refugees (Börzel \& Risse, 2018, p. 90). The suggested European Border and Coast Guard has so far only established incrementally. The only successful measure to contain immigration was agreed with a non-EU member, Turkey.
According to this 6 billion Euro deal, for each 'irregular' migrant that Turkey takes back from Greece, the EU would resettle one Syrian refugee from Turkey. In the wake of this deal, the number of migrants dropped sharply in 2016. What is more, due to resistance by the V4 (and other reluctant member states), there is up to now no prospect for a viable agreement on any permanent relocation system for refugees.

\section{Incentives and Disincentives to Cooperate within the Visegrád Format}

This section illustrates that the emergence of the V4 as a transnational platform against further European integration was all but self-explanatory. Within the Visegrád format, the governments of Poland, Hungary, the Czech Republic, and Slovakia cooperate with each other. The Visegrád countries owe their name from a scenic town in Hungary where the Presidents of Czechoslovakia, Poland, and Hungary agreed to meet on a regular basis in February 1991. Originally, the V4 had hardly any common interest but EU accession. In contrast to the Benelux Group or Nordic Cooperation, there was no permanent Visegrád organization apart from a modest International Visegrád Fund (5 million Euros per year) devoted to sponsoring projects in education, arts/culture, and science and technology. Structural differences between the V4 prevailed. Poland as the largest country always possessed a variety of alternative diplomatic options the smaller Visegrád countries lacked. The Czech Republic always valued its relationship with neighboring Germany as more important than that with any of its Visegrád allies (Nič, 2016, p. 288). Additionally, the relation between the Czech Republic and Slovakia were initially difficult once the latter broke away from the former Czechoslovakia in 1992.

Given the lack of common interests among the V4, the EU represented the most significant external power to influence their polities after 1989. V4 was one of the first sub-regional groupings to emerge in the post-cold war environment. It was modelled along the lines of the Benelux group and Nordic cooperation in the sense that it basically consisted of elite governmental meetings largely confined to the top-level political sphere. Three distinct phases of V4 cooperation are identifiable: 1990-1992, 1993-1998, and 1998-2004 (Dangerfield, 2008). In the first phase, cooperation focused on two key objectives: the dissolution of the Soviet-era security and integration structures and accession to the EU and NATO. For this reason, the V3 engaged in mutual trade liberalization. The second phase was characterized by an ice age due to split of Czechoslovakia into two countries and the ensuing Slovak flirt with authoritarianism under Vladimír Mečiar (1994-1998). Only in 1998, the V4 were able to agree on a common strategy for EU-accession again. At a meeting in Bratislava in 1999, the V4 countries defined the Visegrád format more thoroughly. From then on, there were to be two regular meetings per year of the 
V4 Prime Ministers, two regular meetings per year of foreign ministers, meetings of other ministers as and when needed, and meetings of presidents and parliamentary representatives (Dangerfield, 2008, p. 645). Additionally, the "V4 plus" formula provided the framework for the V4 to cooperate, as a group, with third parties. In terms of its content, the $\mathrm{V} 4$ agreed to cooperate in eight policy areas (Strážay, 2014, p. 38).

However, relations between the V4 remained conflict-ridden. In 2002, a dispute between the Czech Republic and Hungary ensued about the question whether the Beneš decrees of the 1940-1945 period (during which Czechoslovakia was occupied by Nazi Germany) were compatible with future EU membership (Dangerfield, 2008, p. 647). In the same year, Poland departed from the common V4 line at an EU summit and, to the big disappointment of its partners, dropped its demand to significantly increase agricultural compensation payments in return for one billion Euro lump sum payment from EU. In return, the other Visegrád countries did not help the Polish government-that at the time was eager to play an active part in shaping major EU policies central to its own interest and ambitionsdefending the Nice Treaty in 2004. Against this background, Visegrád cooperation was in dire straits at the moment of EU-accession (Nič, 2016, p. 283).

After EU-accession, there only remained two V4 goals: access to EU cohesion funds and Schengen membership (both of which the V4 achieved in December 2007). Free movement within the EU was particularly desirable for the V4 since their populations were most interested in migrating to other EU countries such as Britain, France, Germany, the Netherlands, and Sweden in order to work there. Indeed, internal migration within the EU increased remarkably after 2007 (see Black, Engbersen, Okólski, \& Panțîru, 2010). Once Schengen accession was completed in December 2007, new problems between the V4 arose (Nič, 2016, pp. 284-285). There were diplomatic spats between Slovakia and Hungary over the former's 2009 Language Law Amendment, followed by controversies over the nationalist agenda in Budapest when Viktor Orbán's Fidesz came to power in 2010. Poland's strong anti-Russia stance clashed with Hungary's privileged partnership with Moscow over the Ukrainian crisis in 2014.

The refugee crisis can be regarded as yet another disruption in V4 relations because, albeit being of primordial importance in recent elections throughout all Visegrád countries, it had different impacts on their respective party systems. In Hungary and Poland, populist far-right government parties benefitted from the crisis. In Hungary, the already governing Fidesz could further increase its vote share in 2018, not least by exploiting anti-immigrant policy positions. The 2015 elections in Poland demonstrated the potency of the refugee issue as an electoral asset for mainstream parties. PiS (Law and Justice Party) exploited public anger at the outgoing Civic Platform government-that had voted in fa- vor of the refugee quotas for fear of being isolated in the EU-to increase its appeal to voters on the far-right and also to center-right voters whose concerns were rooted in fears about the consequences of immigration. In contrast, campaigning against refugees backfired on the establishment parties in both the Czech Republic and Slovakia, that lost votes to right-wing contenders in line with the logic outlined in the previous section (Bustikova \& Guasti, 2018, p. 172).

Despite the different partisan composition of V4 governments, the recent elections did not necessarily produce an "illiberal axis" (Nič, 2016, p. 281) of Hungary and Poland against the more liberal Czech Republic and Slovakia. Public opinion in all V4 countries has been-and still is-strongly opposed to immigration from outside Europe. The background of this opposition is that the V4 have virtually no experience with immigration. It was only after 2004 that the new member states of the EU for the first time in their history became destination for migration. Therefore, non-native citizens still constitute a very small share of the populations of the Czech Republic (eight percent), Hungary, Slovenia, and Poland (less than five percent each; Kobierecka \& Riegl, 2016, p. 21).

Given the reservations against immigration from outside Europe among the V4 countries, there are signs that their common rejection of relocation plans has trumped all other divides. On the one hand, it is true that only Poland and Hungary have so far refused to take any asylum-seeker under the EU scheme while Slovakia and the Czech Republic have taken in some refugees (Bustikova \& Guasti, 2018, p. 172). On the other hand, the Slovak government joined its Hungarian counterpart in an (unsuccessful) attempt to dispute the EU refugee quotas at the European Court of Justice in May 2017. At the same time, Poland became increasingly isolated in Brussels (Nič, 2016, p. 287) and, accordingly, more than ever likely to rely on its V4 partners.

To conclude, there are both hindrances and incentives for the V4 to cooperate, that is to create mutual benefits, rather than merely coordinate their actions with the aim to render them more predictable (see Elster, 2007, p. 317). This raises the question: Which goal did their apparent cooperation in the wake of the refugee crisis aim to achieve? As we will see in the following section, intergovernmentalism and postfunctionalism would answer this question differently.

\section{V4 Cooperation as a Case of Governmental or Partisan Transnationalism?}

While the intergovernmentalist perspective emphasizes the governmental aspect of transnational cooperation, the postfunctionalist perspective focuses on partisan aspects. From an intergovernmentalist perspective, their common interest in free movement within the EU and access to cohesion funds trumped the V4's governments' partisan differences and experiences and gave rise to increasing levels of cooperation to fend off negative effects 
of the refugee crisis and maintain the status quo. In contrast, from a postfunctionalist perspective, the politicization of migration in the wake of the refugee crisis has led to closer cooperation among the V4.

Intergovernmentalism regards differences in integration preferences and bargaining dynamics as sufficient to explain the variation in political reform outcomes. While the realist variant regards member states' security interests as primordial to explain the evolution of regional integration (Hoffmann, 1966), liberal intergovernmentalism emphasizes the importance of economic preferences as expressed by interest organizations (Moravcsik, 1998). Both forms of intergovernmentalism are compatible with each other if one assumes that whenever security interests are diffuse, economic ones prevail (and vice versa; see Schimmelfennig, 2018, p. 9).

Biermann et al. (2019) explain EU member states' responses to the refugee crisis from a liberal intergovernmental perspective. According to these authors, the uneven impact of the refugee crisis explained why some states supported the relocation scheme and others did not. Since the majority of member states were unaffected by the crisis, they had a better bargaining position and could maintain the status quo (of non-reform) since 2015 (see also Zaun, 2018). But what about the Hungarian position? Hungary clearly is an outlier to the explanation presented above as it has the secondhighest number of asylum-seekers per 100,000 inhabitants after Sweden, so it can hardly be classified as non-affected but nonetheless expressed a clear preference for the maintenance of the regulatory status quo. Biermann et al. (2019) argue that Hungary is de facto unaffected because all asylum applications were turned down. This, however, itself warrants an explanation. So why did the V4 cooperate in the wake of the refugee crisis despite the latter's different impact and the variation in bargaining power among V4 partners? From an intergovernmental perspective, we would expect shared economic (liberal intergovernmentalism) or security interests (realist intergovernmentalism) among V4 partners to explain their cooperation.

Postfunctionalism provides an alternative approach to explain V4 cooperation. Just like intergovernmentalism, postfunctionalism also starts from assumption that member states are central actors in European integration. However, postfunctionalism puts more emphasis to an identity approach. Given the increased salience of a transnational cleavage, the conflict between green-alternative-libertarian (GAL) and traditionalauthoritarian-nationalist (TAN) values arguably plays an increasingly more important role that the utilitarian conflict of economic preferences emphasized by liberal intergovernmentalism (Hooghe \& Marks, 2009, 2018). According to postfunctionalism, territorial identity serves as "perhaps the most powerful source of mass political mobilization" (Hooghe \& Marks, 2018, p. 113).

There certainly is empirical evidence for an increasing importance of the GAL vs. TAN conflict. Even prior to the refugee crisis, Euroscepticism has always been linked to exclusionist nationalism (de Vries \& Edwards, 2009). After the refugee crisis, right-wing parties arguably were the major beneficiaries of this politicization (Börzel \& Risse, 2018; Geddes \& Scholten, 2016). In general, support for right-wing Eurosceptic and populist parties across Europe is driven by exclusive nationalism and culturally based anti-immigrant attitudes (Werts, Scheepers, \& Lubbers, 2013). What is more, established parties fail to respond adequately as they are, more often than not, deeply divided internally over European integration. Against this background, the refugee crisis could well be regarded as a critical juncture increasing the politicization of migration within the EU.

Politicization is a core concept of postfunctionalism that explains the shift from a permissive consensus (Lindberg \& Scheingold, 1970, p. 41) to a constraining dissensus on European integration (Hooghe \& Marks, 2009, p. 5). The result of this process is a newly dominant cleavage that Hooghe and Marks (2018, p. 110) term transnational "because it has as its focal point the defense of national political, social and economic ways of life against external actors who penetrate the state by migrating, exchanging goods or exerting rule." Politicization has three dimensions: salience (visibility), mobilization (beyond the mere sphere of elites), and polarization (intensity of conflict; Grande \& Hutter, 2016, pp. 8-10). From a postfunctionalist perspective, V4 cooperation could be regarded as partisan in the sense that it serves as a means to express anti-immigration sentiments. Given the unanimous rejection of immigration from outside Europe among the V4 populations, the migration crisis as a critical juncture has arguably led to a "major shift in the relationships between the four Central European countries that make up the Visegrád Group" (Nič, 2016, p. 281) and caused them to cooperate.

However, the postfunctionalist perspective also leaves some questions open. Given the existence of a transnational cleavage, why would governments of different partisan compositions cooperate to express common positions on a highly politicized issue such as migration? In order to answer this question, we need to assess whether the V4 really claimed to respond to public concerns about immigration or aim to mobilize political support against immigration-or whether they emphasized shared economic or security interests (as intergovernmentalism posits). To do so, we engage in a sequence elaboration (Mahoney, Kimball, \& Koivu, 2009) of press statements following the V4's most important event, the meetings of Prime Ministers after EU-accession in 2004. The term 'sequence' refers to connected events that unfold over time. Sequence elaboration can help to establish causal relations. From a temporal perspective, the closer the necessary conditions are to the outcome of interest in which they occur-here the establishment of the V4 as a "cohesive bloc" (Nič, 2016, p. 281) in early 2016-the more important they will be (see Mahoney et al., 2009, p. 132). 
Our focus is on V4 Prime Ministers' press statements because these display voluntary commitments. For all these statements, we identified the topics V4 Prime Ministers committed themselves to. It did not suffice for a certain topic to be merely touched upon. Rather, the V4 Prime Ministers needed at least to briefly elaborate a common position on a particular topic such as a shared demand for action. The V4 Prime Ministers' press statements are particularly well suited for a sequence elaboration because they conventionally follow each of the halfyearly meetings of V4 Prime Ministers (sometimes there was even more than one statement related to a meeting). These press statements are drafted consensually. From this follows that if there is no willingness among V4 governments to enter any commitment, a topic is left out of our analysis.

We assert that several temporal aspects indicate that the causal relevance of a topic referred to in V4 Prime Ministers' press statements increases as a reason underlying transnational cooperation: a) the higher the frequency of press statements it is referred to in; $b$ ) the temporally closer the meetings occurred to the refugee crisis and especially V4 cohesion in early 2016; and c) the more detailed-that is, longer-these statements are. Against the background of the topics different theories of integration emphasize, the main question we ask in the following content analysis of V4 Prime Ministers' press statements is whether economic (liberal intergovernmentalism), security (realist intergovernmentalism), or identity issues (postfunctionalism) feature more prominently with respect to their frequency, temporal location, and elaboration. Our analysis is inductive which means that we take all topics mentioned in the press statements into consideration.

\section{An Analysis of Visegrád Prime Ministers' Press Statements}

We examined a total of 50 press statements originating from 35 meetings of Prime Ministers in the 2004mid-2018 period. All these press statements are listed in the supplementary file available online. Our analysis in Table 1 starts with the frequency of meetings and topics over the whole 2004-2018 period, but also in the preand post-2015 periods in order to assess the impact of the refugee crisis that enrolled in 2015. The frequency of V4 Prime Ministers' meetings (see the last line in Table 1) changed remarkably before and after 2015. There was a total of 50 meetings equaling 3.4 meetings per year. Before 2015, only 2.5 meetings took place annually. This number rose to 6.6 after 2015. Put differently, the frequency of V4 Prime Ministers' meetings more than doubled after 2015. This suggests that the refugee crisis politicized the V4 and caused them to mobilize support.

Table 1. Frequency (per year) of topics mentioned in Prime Ministers' meetings' press statements (total numbers in brackets).

\begin{tabular}{|c|c|c|c|c|}
\hline & & 2004-2018 & 2004-2014 & 2015-2018 \\
\hline \multicolumn{2}{|c|}{ Economic matters * } & $1.9(28)$ & $1.3(14)$ & $4(14)$ \\
\hline \multirow[t]{4}{*}{ Of which on } & Schengen/freedom of labor market & $0.9(13)$ & $0.5(6)$ & $2(7)$ \\
\hline & cohesion funds/redistribution & $0.6(9)$ & $0.5(6)$ & $0.9(3)$ \\
\hline & financial/Eurozone crisis & $0.1(2)$ & $0.2(2)$ & 0 \\
\hline & other topics $* *$ & $0.7(10)$ & $0.4(4)$ & $1.7(6)$ \\
\hline \multicolumn{2}{|c|}{ Security matters * } & $1.5(22)$ & $1.3(14)$ & $2.3(8)$ \\
\hline \multirow[t]{3}{*}{ Of which on } & international crises related to migration *** & $0.3(5)$ & $0.2(2)$ & $0.9(3)$ \\
\hline & international crises unrelated to migration $* * * *$ & $1(14)$ & $0.9(10)$ & $1.1(4)$ \\
\hline & defense cooperation $* * * * *$ & $0.7(10)$ & $0.5(6)$ & $1.1(4)$ \\
\hline \multicolumn{2}{|l|}{ EU matters * } & $0.6(9)$ & $0.5(6)$ & $0.9(3)$ \\
\hline \multirow[t]{2}{*}{ Of which on } & enlargement & $0.4(6)$ & $0.4(4)$ & $0.6(2)$ \\
\hline & integration/constitutional treaties & $0.3(5)$ & $0.4(4)$ & $0.3(1)$ \\
\hline \multicolumn{2}{|c|}{ V4 specific matters * } & $0.7(10)$ & $0.5(6)$ & $1.1(4)$ \\
\hline \multirow[t]{2}{*}{ Of which on } & presidency & $0.6(8)$ & $0.5(5)$ & $0.9(3)$ \\
\hline & Visegrád fund & $0.6(8)$ & $0.5(6)$ & $0.6(2)$ \\
\hline \multicolumn{2}{|c|}{ Identity matters: Concern about immigration into EU } & $1.2(17)$ & $0.1(1)$ & $4.3(16)$ \\
\hline \multicolumn{2}{|c|}{ Total frequency of statements * } & $3.4(50)$ & $2.5(27)$ & $6.6(23)$ \\
\hline
\end{tabular}

Notes: * Note that the references to the topics mentioned here do not add to the total number of press statements (neither for particular matters nor regarding all statements) since individual statements could include references to several topics; ${ }^{* *}$ Food ( $\left.2 x\right)$, economic cooperation with third countries (Japan, Switzerland, France, South Korea, Egypt, Israel), transport cooperation, digitalization; ${ }^{* * *}$ Western Balkan (3x), Arab spring, Paris terrorist attacks; **** Ukraine (11x), Georgia (2x), Belarus; ***** Either among V4 or with other countries such as Japan, Switzerland, France, South Korea, Israel. Topics in italics are further analyzed as potentially explaining if and why the refugee crisis triggered a politicization of the V4. 
A closer look at the topics covered reveals that V4 Prime Ministers indeed communicated on meaningful issues. Five broad categories played a substantial role (in bold in Table 1): economic; security; EU matters; identity matters; and those related to V4-specific matters. The last category only came second to last in overall frequency (before European matters that played a negligible role). This suggests that the V4 were not only occupied with themselves. All more frequently mentioned matters are related to potential causal factors mentioned in the previous section. The most important category is economic matters that are overall almost mentioned twice a year and four times a year after 2015. Security matters are clearly less often mentioned. Remarkably, identity matters - that is, immigration-are touched upon most often in the post-2015 period (4.3 times per year, more than any other topic). This further suggests that the refugee crisis politicized the V4.

It needs to be pointed out that not all economic and security matters referred to in the V4 statements could be linked to the refugee crisis. For this reason, we further subdivided these categories to separate those topics possibly related to the refugee crisis from those unrelated. For economic matters, all references to the integrity of the Schengen area and the maintenance of redistribution within the EU could be related to migration. As Table 1 illustrates, these issues were clearly more frequently mentioned than the Eurozone crisis and other issues. Similarly, their frequency rose after 2015. The same is true for security matters, among which, however, international crises related to migration were overall mentioned less frequently. Most security topics mentioned in V4 press statements were not related to the refugee crisis, notably the Ukraine crisis that enrolled in 2013.

We continue our analysis by further investigating the sequence of press statements referring to topics that are potentially related to the refugee crisis (displayed in italics in Table 1). As Figure 1 illustrates, these statements clearly cluster in the post-2015 period. Throughout the 2004-2018 period, V4 Prime Ministers regularly committed themselves to action in international migrationrelated crises and, in particular, to maintaining redistribution within the EU and free movement within the
Schengen area. However, such commitments became more frequent once the refugee crisis broke out. During the July 2015 to June 2016 period, there was the (until then) exceptional number of four Prime Ministers' meetings that all aimed to develop a common position on the refugee crisis in preparation of meetings at the supranational level. As Figure 1 suggests, references to migration initially also corresponded with references to security concerns, but then became clearly associated with economic concerns since the second half of 2015 when the V4 became a brand. This suggests that, while economic and security commitments were always present, a politicization suggested by the post-2015 cluster of statements only occurred once immigration became a concern.

In line with our findings from Table 1 and Figure 1, the evidence presented in Table 2 also suggests that there were not only more statements after 2015, but also longer ones. This was especially true for economic commitments to Schengen and redistribution, on which statements with an average of 832 words were issued before 2015, a number that grew to 2,370 after the refugee crisis broke out. The single most important topic was immigration itself to which statements averaging 5,294 words per year were issued after 2015. The increasing length of press statements further suggests that V4 cooperation grew after 2015. EU-related and V4-specific matters clearly played a less prominent role than migrationrelated economic commitments. The only exception with respect to migration-unrelated issues is general security matters, press statements on which had an average length of 2,353 words after 2015. We relate this to the geographical proximity of the Ukraine crisis that almost paralleled the refugee crisis. However, the sharply rising length of press statements on immigration and immigration-related economic issues suggests that the refugee crisis either induced governmental or partisan transnational cooperation.

In order to further assess whether the apparent politicization of the V4 went back to governmental economic interests as posited by liberal intergovernmentalism or partisan motivations to mobilize against immigration as suggested by postfunctionalism, we take a

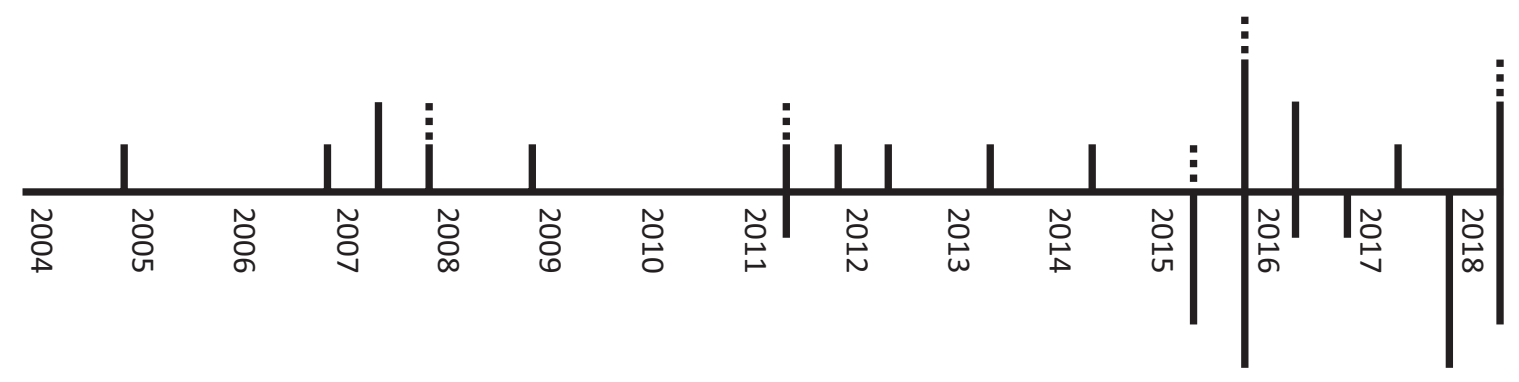

| One press statement referring to economic interests (above timeline) or migration (below timeline)

One statement referring to security interests

Figure 1. Timeline of V4 Prime Ministers' meetings' press statements, 2004-2018. 
Table 2. Annual number of words devoted to topics in Prime Ministers' meetings' press statements (annual number of statements multiplied by average words in brackets).

\begin{tabular}{|c|c|c|c|}
\hline & 2004-2018 & 2004-2014 & 2015-2018 \\
\hline \multirow[t]{2}{*}{ Economic matters * } & 1,804 & 1,059 & 4,148 \\
\hline & $(1.9 * 934)$ & $(1.3 * 832)$ & $(4 * 1037)$ \\
\hline \multirow[t]{4}{*}{ Of which } & 1,224 & 832 & 2,370 \\
\hline & $(1.3 * 934)$ & $(1 * 832)$ & $2.3 * 1037$ \\
\hline & 954 & 633 & 1,963 \\
\hline & $(0.8 * 832)$ & $(0.5 * 1160)$ & $(1.7 * 1145)$ \\
\hline \multirow[t]{2}{*}{ Security matters * } & 1,520 & 976 & 3,365 \\
\hline & $(1.5 * 1002)$ & $(1.3 * 767)$ & $(2.3 * 1472)$ \\
\hline \multirow[t]{4}{*}{ related to migration } & 327 & 93 & 1,062 \\
\hline & $(0.3 * 948)$ & $(0.2 * 511)$ & $0.9 * 1239)$ \\
\hline & 1,245 & 968 & 2,353 \\
\hline & $(1.2 * 1003)$ & $(1.2 * 805)$ & $(1.4 * 1647)$ \\
\hline \multirow[t]{2}{*}{ EU matters } & 492 & 369 & 879 \\
\hline & $(0.6 * 793)$ & $(0.5 * 677)$ & $(0.9 * 1025)$ \\
\hline \multirow[t]{2}{*}{ V4 specific matters } & 769 & 489 & 1,650 \\
\hline & $(0.7 * 1115)$ & $(0.5 * 896)$ & $(1.1 * 1444)$ \\
\hline \multirow[t]{2}{*}{ Identity matters: Concern about immigration } & 1,376 & 94 & 5,294 \\
\hline & $(1.2 * 1150)$ & $(0.1 * 1029)$ & $(4.6 * 1158)$ \\
\hline \multirow[t]{2}{*}{ All statements * } & 2,793 & 1,576 & 6,617 \\
\hline & $(3.4 * 810)$ & $(2.5 * 642)$ & $(6.6 * 1007)$ \\
\hline
\end{tabular}

Notes: ${ }^{*}$ Note that the page numbers for the topics mentioned here do not add to the total number of pages (neither for particular matters nor regarding all statements) since individual statements could include references to several topics. Topics in italics are further analyzed as potentially explaining if and why the refugee crisis triggered a politicization of the V4.

closer look at the arguments and commitments the V4 Prime Ministers presented after 2015. Immigration was initially conceived of as a security problem: "In the South, a belt of weak and destabilized states now stretches from North Africa via the Horn of Africa to Iraq and Yemen, creating an environment conducive to challenges like unprecedented migration flows" (V4 Prime Ministers, 2015b). Against this background, the V4 Prime Ministers criticized that the European Council proposal "fails to address and find adequate solutions to migration pressure from and via the Western Balkan route as well as the Eastern route" because any mandatory redistribution of migrants would serve as a "pull factor" of further immigration only to be countered by the "effective return" of immigrants without a status as asylum-seekers (V4 Prime Ministers, 2015b; see also V4 Prime Ministers, 2017e).

However, this conclusion already suggested an economic perspective, because it was work immigration that the V4 were most critical of. In a simultaneous meeting with France, the V4 Prime Ministers concluded that "V4 and France consider the free movement of workers and freedom to provide services as fundamental principles of the internal market and important factors for economic growth" (V4 Prime Ministers, 2015a). The V4 Prime Ministers did not further elaborate on these arguments during the first of their chain of extraordinary meetings beginning in the second half of 2015. Rather, they expressed their full "solidarity" with Hungary (V4 Prime Ministers, 2015c) and developed ideas how to fend off immigration: In September 2015, V4 Prime Ministers began to refer to the need to manage the "root causes" of migration and to create hotspots to register and, if possible, return irregular migrants. Together with their emphasis on the "voluntary nature of EU solidarity measures," this created the impression that the V4 Prime Ministers primarily aimed to mobilize support against immigration into the EU as such (V4 Prime Ministers, 2015c).

However, before the V4 clearly emerged as a brand in early 2016, this line of argumentation was augmented economically. The V4 December 2015 Statement clarified the common benefit of anti-immigration cooperation beyond identity politics: Whilst acknowledging that "allocating adequate financial resources in the European Union budget" was necessary to deal with the refugee crisis, the V4 Prime Ministers emphasized that "other essential European policies, namely growth-oriented instruments such as cohesion policy, must not be affected" (V4 Prime Ministers, 2015d). In line with this, they continued to emphasize that:

Schengen remains a key practical and symbolic achievement of European integration. We reaffirm our determination to preserve Schengen so that European citizens and businesses continue to fully enjoy its benefits. We underline the need for respecting Schengen rules and declare our openness to discuss how to best improve them. A proper functioning of 
Schengen and the preservation of free movement is not a divisive issue but must remain the key objective for all Member States and the European Union institutions. (V4 Prime Ministers, 2015d)

Remarkably, it was at this stage that the V4 Prime Ministers apparently attempted to mobilize support for the first time when they expressed their willingness to extend their cooperation and organize like-minded member states in a group of "Friends of Schengen" (V4 Prime Ministers, 2015d). This suggests that the V4 refusal of irregular immigration in general and mandatory relocation of migrants in particular primarily aimed to maintain the principle of free movement within the EU. As mentioned above, it was at this time that the Dutch, Austrian, and German governments launched their proposal to narrow the Schengen area since the free movement principle had effectively been suspended by then. Against this proposal, the V4 emphasized the need to "preserve Schengen" including a "call on all true friends of Schengen to join this effort towards a conclusive debate on the key proposals tabled by the European Commission in this respect" (V4 Prime Ministers, 2015e). Yet another appeal to the friends of Schengen and, remarkably, only then the at that time usual suggestions to deal with migration proper such as border controls and the creation of hotspots with detention capacity (V4 Prime Ministers, 2015e). In a similar vein, the V4 in 2017 refused Commission plans to complicate the posting of workers within the EU (V4 Prime Ministers, 2017a). This suggests that in the immediate run-up to the emergence of the V4 as a brand, their primary preferences were economic ones-in line with liberal intergovernmentalist assumptions. However, the V4 only politicized this preference once they could simultaneously politicize an identity issue-as suggested by postfunctionalism.

After 2016, the pattern which had by then emerged continued: V4 publicly denounced the Commission's plan to relocate migrants (V4 Prime Ministers, 2016, 2017d; 2018a; 2018c) and ultimately justified this with economic reasons, primarily the need to maintain the Schengen acquis. In meetings with or letters to other heads of governments, be it from Egypt (V4 Prime Ministers, 2017b), Israel (V4 Prime Ministers, 2017c), or Italy (V4 Prime Ministers, 2017d), the V4 emphasized the need to address the "root causes" of migration which for them apparently was economic despair. In line with this, the V4 continued to call for returning all merely economically motivated asylum seekers outside EU territory. The nexus between identity and economic issues became even more apparent when the V4 Prime Ministers stressed that only well-protected external borders allowed for internal freedom of (work) migration: "We need to be able to fully protect the external borders of the European Union. At the same time, we need to remove internal border controls" (V4 Prime Ministers, 2017e). In 2018, they became even more explicit about this nexus:
We must restore the proper functioning of Schengen, as well as regaining full control over the external borders. Equally we must protect and further develop the Single Market based on four fundamental freedoms, including the free movement of workers and services. (V4 Prime Ministers, 2018a)

The economic reasons for the V4 Prime Ministers' continuous rejection of immigration were not exclusive confined to the maintenance of work migration and the Schengen acquis. As the frequency, sequence, and elaboration of issues emphasized in their press statements suggested, the V4 also emphasized the beneficial impact of EU cohesion policy as "very efficient in reducing disparities among the regions" (V4 Prime Ministers, 2018c). With the exception of border controls, the V4 accordingly opposed any allocation of EU money to migration policies at the detriment of cohesion policy. In contrast, direct links between security and migration issues remained rare after 2016 (see for instance the joint statement with the Austrian Prime Minister, V4 Prime Ministers, 2018b).

\section{Conclusion: Opposing Immigration to Maintain Migration}

The question underlying this article was whether politicization in the EU has led to closer cooperation among the V4 as a subgroup of EU member states against the backdrop of the refugee crisis. We could indeed link the emergence of the V4 as transnational challengers of supranational integration to both the refugee crisis and the process of politicization this triggered. However, our findings partially contradict the doctrines of both liberal intergovernmentalism and postfunctionalism. In contrast to postfunctionalist assumptions, governments appeared as the main actors of politicization irrespective of their partisan composition and primarily focused on economic rather than identity issues. As we have seen, the emphasis on maintaining intra-EU migration under the Schengen acquis was temporally most proximate toand, accordingly causally most relevant for-the emergence of the V4 as a brand. However, the fact that V4 governments did engage in politicization by means of publicly calling on "Friends of Schengen" (V4 Prime Ministers, 2015d, 2015e) and did only successfully do so when simultaneously politicizing identity issues contradicts the assumptions of liberal intergovernmentalism.

From this we conclude that the "politics turn" (Braun, Gross, \& Rittberger, 2020, p. 1) in research on the EU is indeed justified. We suggest that an emphasis on politics should aim to synthesize intergovernmental and postfunctionalist explanations (see also Schimmelfennig, 2018): Under the condition of increasing politicization, postfunctionalist identity issues help to forge classic liberal intergovernmentalist alliances of governments. This suggests that the recent politicization of the EU is more ambivalent than often assumed: It gives rise 
not only to far-right parties benefitting from (and promoting) Euroscepticism, but also to economic preferences to maintain core achievements of European integration such as free movement within the EU. Since the pattern of transnational cooperation fitted neither the governmental nor the partisan assumption, we regard the post-2015 V4 cooperation as a case of politicized transnationalism - that is, cooperation to achieve transnational aims such as the maintenance of freedom of movement under the condition of politicization.

It needs to be pointed out that our sequence elaboration fell short of a fully-fledged process-tracing analysis. For this reason, we could only tentatively contribute towards a causal mechanism explaining V4 cooperation that requires to be further fleshed out based on a broader empirical basis. However, our sequence could serve not only as the starting point for such process-tracing analyses, but also for other analyses of other member states' responses to the refugee crisis. Admittedly, a politicization of economic issues was easier to achieve in Central and Eastern Europe, where economic and GAL vs. TAN conflicts are not cross-cutting, but mutually reinforcing (Hooghe \& Marks, 2012, p. 844). However, it seems promising to expand our focus beyond Central and Eastern Europe and investigate how other transnational forums such as the Nordic Council, the six founding members of the EU, the Franco-German alliance, and the so-called Mediterranean club have responded to the critical juncture of the refugee crisis. In the wake of the refugee crisis, we should expect governments to increasingly respond to widely shared sentiments of their electorates irrespective of partisan composition.

\section{Acknowledgments}

We acknowledge support by the Open Access Publication Funds of the SLUB/TU Dresden and we wish to thank the academic editors and the anonymous reviewers of this thematic issue for their extremely helpful comments on our manuscript. The usual disclaimer applies.

\section{Conflict of Interests}

The authors declare no conflict of interests.

\section{Supplementary Material}

Supplementary material for this article is available online in the format provided by the authors (unedited).

\section{References}

Beisel, K. M. (2019, March 7). Nichts zu besprechen [Nothing to discuss]. Süddeutsche Zeitung. Retrieved from https://www.sueddeutsche.de/politik/ migration-nichts-zu-besprechen-1.4359148

Biermann, F., Guérin, N., Jagdhuber, S., Rittberger, B., \&
Weiss, M. (2019). Political (non-)reform in the euro crisis and the refugee crisis: A liberal intergovernmentalist explanation. Journal of European Public Policy, 26(2), 246-266.

Black, R., Engbersen, G., Okólski, M., \& Panțîru, C. (Eds.). (2010). A continent moving West? EU enlargement and labour migration from Central and Eastern Europe. Amsterdam: Amsterdam University Press.

Börzel, T. A., \& Risse, T. (2018). From the Euro to the Schengen crises: European integration theories, politicization, and identity politics. Journal of European Public Policy, 25(1), 83-108.

Braun, D., Gross, M., \& Rittberger, B. (2020). Political behavior in the EU multi-level system. Politics and Governance, 8(1), 1-5.

Bustikova, L., \& Guasti, P. (2018). The illiberal turn or swerve in Central Europe? Politics and Governance, 5(4), 166-176.

Dangerfield, M. (2008). The Visegrád group in the expanded European Union: From preaccession to postaccession cooperation. East European Politics and Societies, 22(3), 630-667.

de Vries, C. E., \& Edwards, E. E. (2009). Taking Europe to its extremes: Extremist parties and public Euroscepticism. Party Politics, 15(1), 5-28.

Elster, J. (2007). Explaining social behavior. Cambridge: Cambridge University Press.

Geddes, A., \& Scholten, P. (2016). The politics of migration \& immigration in Europe (2nd ed.). Los Angeles, CA: Sage.

Grande, E., \& Hutter, S. (2016). Introduction: European integration and the challenge of politicisation. In S. Hutter, E. Grande, \& H. Kriesi (Eds.), Politicising Europe (pp. 3-31). Cambridge: Cambridge University Press.

Hoffmann, S. (1966). Obstinate or obsolete? The fate of the nation state and the future of Western Europe. Daedalus, 95(4), 861-898.

Hooghe, L., \& Marks, G. (2009). A postfunctionalist theory of European integration: From permissive consensus to constraining dissensus. British Journal of Political Science, 39(1), 1-23.

Hooghe, L., \& Marks, G. (2012). Politicization. In E. Jones, A. Menon, \& S. Weatherill (Eds.), The Oxford handbook on the EU (pp. 840-854). Oxford: Oxford University Press.

Hooghe, L., \& Marks, G. (2018). Cleavage theory meets Europe's crises: Lipset, Rokkan, and the transnational cleavage. Journal of European Public Policy, 25(1), 109-135.

Kobierecka, A., \& Riegl, M. (2016). Introduction. In R. Łoś \& A. Kobierecka (Eds.), The V4 towards migration challenges in Europe: An analysis and recommendations (pp. 9-27). Łódź: Wydawnictwo Uniwersytetu Łódzkiego.

Lindberg, L. N., \& Scheingold, S. A. (1970). Europe's would-be polity: Patterns of change in the European Community. Englewood Cliffs, NJ: Prentice-Hall. 
Mahoney, J., Kimball, E., \& Koivu, K. (2009). The logic of historical explanation in the social sciences. Comparative Political Studies, 42(1), 114-146.

Moravcsik, A. (1998). The choice for Europe: Social purpose and state power from Messina to Maastricht. Ithaca, NY: Cornell University Press.

Nič, M. (2016). The Visegrád group in the EU: 2016 as a turning-point? European View, 15(2), 281-290.

Schimmelfennig, F. (2018). Theorien der europäischen Integration [Theories of European integration]. In P. Becker \& B. Lippert (Eds.), Handbuch Europäische Union [European Union handbook] (pp. 1-23). Wiesbaden: Springer.

Strážay, T. (2014). Neither beautiful nor ugly, but functional: A pragmatic view on the Visegrad Group. Contemporary European Studies, 2(2), 37-47.

Szczerbiak, A., \& Taggart, P. (Eds.). (2008). Opposing Europe? The comparative party politics of Euroscepticism. Vol. 1.: Case studies and country surveys. Oxford: Oxford University Press.

Thorpe, N. (2016, February 21). Visegrad: The castle where a Central European bloc was born. BBC. Retrieved from https://www.bbc.com/news/magazine35613206

V4 Prime Ministers. (2015a, June 19). Press statement on the occasion of the summit of V4 Prime Ministers and the President of the French Republic [Press release]. Retrieved from http://www.visegradgroup. eu/calendar/2015/press-statement-on-the

V4 Prime Ministers. (2015b, June 19). Joint statement of the Heads of Government of the Visegrad Group countries [Press release]. Retrieved from http://www.visegradgroup.eu/calendar/2015/jointstatement-of-the

V4 Prime Ministers. (2015c, September 4). Joint statement of the Heads of Government of the Visegrad Group countries [Press release]. Retrieved from http://www.visegradgroup.eu/calendar/2015/jointstatement-of-the-150904

V4 Prime Ministers. (2015d, December 3). Joint statement of the Visegrad Group countries [Press release]. Retrieved from http://www.visegradgroup. eu/calendar/2015/joint-statement-of-the-151204

V4 Prime Ministers. (2015e, December 17). Joint statement of the Visegrad Group countries [Press release]. Retrieved from http://www.visegradgroup.eu/ calendar/2015/joint-statement-of-the-151221-1

V4 Prime Ministers. (2016, February 15). Joint statement on migration [Press release]. Retrieved from http://www.visegradgroup.eu/calendar/2016/jointstatement-on

V4 Prime Ministers. (2017a, May 11). Joint statement of the Prime Ministers of the Visegrad Group on the amendment of posting of workers directive [Press release]. Retrieved from http://www.visegradgroup. eu/calendar/selected-events-in-2017-170203/jointstatement-of-the

V4 Prime Ministers. (2017b, July 4). Joint statement on the occasion of the summit of Prime Ministers of the Visegrad Group and the President of the Arab Republic of Egypt [Press release]. Retrieved from http://www.visegradgroup.eu/calendar/selectedevents-in-2017/04072017-v4-eg-joint

V4 Prime Ministers. (2017c, July 19). Joint statement on the occasion of the annual summit of the Prime Minister of the Visegrad Group and the Prime Minister of the State of Israel Benjamin Netanyahu [Press release]. Retrieved from http://www. visegradgroup.eu/calendar/selected-events-in-2017170203/joint-statement-on-the

V4 Prime Ministers. (2017d, July 19). Letter of the V4 Prime Ministers to the Prime Minister of Italy [Press release]. Retrieved from http://www.visegradgroup. eu/v4-letter-to-the-prime

V4 Prime Ministers. (2017e, July 19). Joint statement by the Prime Ministers of V4 countries on migration [Press release]. Retrieved from http://www. visegradgroup.eu/calendar/v4-declaration-on

V4 Prime Ministers. (2018a, January 26). V4 statement on the future of Europe [Press release]. Retrieved from http://www.visegradgroup.eu/calendar/2018/ v4-statement-on-the

V4 Prime Ministers. (2018b, June 21). Visegrad Group and Austria summit declaration on "Setting up a mechanism for assistance in protecting the borders of the Western Balkan countries" [Press release]. Retrieved from http://www.visegradgroup.eu/ documents/official-statements/visegrad-group-and

V4 Prime Ministers. (2018c, June 21). Stronger together: V4 joint statement [Press release]. Retrieved from http://www.visegradgroup.eu/documents/officialstatements/final-stronger-together

Werts, H., Scheepers, P., \& Lubbers, M. (2013). Euroscepticism and radical right-wing voting in Europe, 2002-2008. European Union Politics, 14(2), 183-205.

Zaun, N. (2018). States as gatekeepers in EU asylum politics. Journal of Common Market Studies, 56(1), 44-62.

\section{About the Authors}

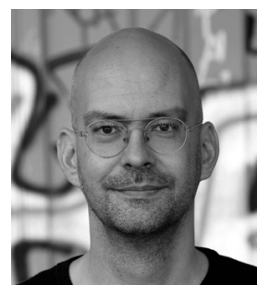

Michael Koß is a Professor for the Political System of Germany and the EU at the Center for the Study of Democracy, Leuphana University Lüneburg. His research focuses on political parties, parliaments, and democracy in Europe. Michael's most recent book, "Parliaments in Time," appeared with Oxford University Press in 2018. He has published in journals such as West European Politics, Comparative Politics, and Regional and Federal Studies. 


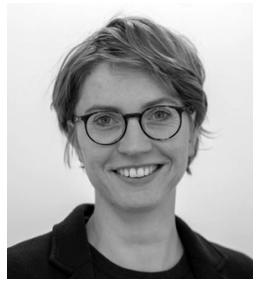

Astrid Séville is an Assistant Professor at the Chair of Political Theory, Geschwister-Scholl-Institute of Political Science at the LMU Munich. She received her PhD in 2015 with a study of the rhetoric of "There is no alternative." For her research, she was granted the German Thesis Award (Deutscher Studienpreis) in 2016. In 2018, she published her second book under the title "Der Sound der Macht. Eine Kritik der dissonanten Herrschaft" [The Sound of Power. A critique of dissonant rule]. 